\title{
Males' Preference for Circumcised Women in Northern Ghana
}

\author{
Evelyn Sakeah', Andy Beke $e^{2}$ Henry V Doctor ${ }^{3}$, and Abraham V Hodgson ${ }^{1}$
}

\begin{abstract}
Female genital mutilation (FGM) still remains one of the challenges facing women in many countries around the world. Efforts to eradicate the practice are on going but the results are still modest due to, among other things, ingrained cultural traditions that expose women to serious health consequences. In Africa where FGM is practiced in more than 28 countries, males have been found to perpetuate the practice. Using baseline data on FGM collected in 1998 by the Navrongo Health Research Centre in Ghana, we examined factors that influence males' choice of marrying circumcised women. Results from regression analysis show that the illiterate and those who have been to primary school are more likely to prefer circumcised women than those with secondary and higher education. In addition, ethnicity and religion are also significant factors that influence males' preference to marry circumcised women. A number of policy implications are discussed. (AfrJ Reprod Health 2006; 10[2]:37-47)
\end{abstract}

\section{RÉSUMÉ}

La préférence chez les hommes pour les femmes excisées au Ghana du nord. La mutilation génitale feminine (MGF) demeure encore un des défis auxquels font face les femmes dans plusieurs pays partout dans le monde. Les tentatives pour éliminer la pratique sont en cours, mais les résultats ne sont encore que modestes dû, entre autres, aux traditions culturelles enracinées qui exposent les femmes aux graves conséquences sur la santé. En Afrique où la MGF est pratiquée dans plus de 28 pays, il a été découvert que les hommes perpétuent la pratique. A l'aide des données de lignes de base sur la MGF recuellies en 1998 par Narrengo Health Research Centre (Centre de Recherche sur la santé de Navrengo) au Ghana, nous avons étudié les facteurs qui influent sur le choix des hommes pour épouser les femmes excisées. Les résultats tirés de l'analyse de regression montrent que les hommes illétrés et celles qui ont été à l'école primaire avaient plus la possibilité de préférer les femmes excisées que ceux qui ont fréquenté les écoles secondaires ou tertiaires. En plus, l'ethnicité et la religion constituent des facteurs importants qui influent sur les préférences chez les hommes pour se marier avec les femmes excisées. Nous avons discuté un certain nombre d'implications de la politique. (Rev Afr Santé Reprod 2006; 10[2]:37-47)

KEY WORDS: Female genital cutting, female genital mutilation, preference, Ghana, sub-Saharan Africa

${ }^{1}$ Navrongo Health Research Centre, P.O. Box 114, Navrongo, UpperEast Region, Ghana. Email:ES: esakeah@yahoo.co.uk, AVH: abodgson@navrongo.mimcom.net ${ }^{3}$ University of the Western Cape, Department of Statistics, Private Bag X17, Bellville 7535, South Africa. Email: bdoctor@uwv.ac.za ${ }^{2}$ University of Pretoria, School of Health Systems and Public Health, Post Office Box 667, Pretoria, South Africa. Email:abeke@medic.up.ac.za 


\section{Introduction}

Female genital mutilation (FGM), also known as female circumcision is defined as the partial or total removal of external female genitalia and injury to the female organs for cultural or other nontherapeutic reason. ${ }^{1}$ The traditional practice of FGM continues to occur in a number of countries worldwide. The prevalence of FGM varies across countries and social institutions behind the practice are multifaceted. Globally, two million girls are at risk of genital mutilation and an estimated 130 million girls and women in the world are so far genitally mutilated. ${ }^{2}$

FGM has been practised for a long time worldwide. For example, the Phoenicians, Hittites, and the ancient Egyptians practised FGM. In England and the United States around the 1940s and the 1950s, FGM was used to "treat" hysteria, lesbianism, masturbation, and other female deviances. Places where FGM is practised include countries of Africa, few in Asia, and among some African immigrants in North and South America, Europe, and Australia., ${ }^{2,3}$

In Africa, FGM is practised in more than 28 African countries. Majority of West African women have also been subjected to this practice. ${ }^{2,4}$ In Ghana, the prevalence rate of FGM is estimated at $5 \%$ based on the 2004 Demographic and Health Survey data on female genital cutting ${ }^{5}$ and the practice is predominant among ethnic groups in the northern than the southern sector. ${ }^{6,7}$ In the Kassena-Nankana District (KND) of northern Ghana for example, the prevalence rate was recorded at $77 \%$ in $1995 .{ }^{8}$

FGM may have serious consequences on women's lives. It often affects the physical, social, and psychological status of women as it involves partial or total removal of the external female genitalia or other injury to the female genital organs whether for cultural or any other nontherapeutic reasons. ${ }^{9,10}$ Four main types of FGM exist: First, clitoridectomy or sunna involves the removal of the clitoral hood with or without removal of all or part of the clitoris. Second, excision varies from the removal of the clitoris and/or clitoral prepuce to the removal of part or the entire clitoris together with part or all of the labia minora (the inner vaginal lips). Third, infibulation involves the removal of the clitoris, the labia minora, and part of the labia majora after which the edges of the wound are sutured to leave a small opening (vaginal orifice). Lastly, the intermediate practice refers to the amputation of the clitoris and parts of the labia minora. ${ }^{1}$

FGM has possible short- and long-term effects. The short-term effects are pain, haemorrhage, shock, and infection whereas the long-term effects consist of scarred tissue, fertility problems, urinary infection, and complications during delivery. The use of one knife to circumcise girls, which is common among traditional practitioners of FGM, could result in HIV transmission including Hepatitis B and C. Infibulation removes larger parts of the genitals and seals the vagina, leaving areas of tough scar tissue in place of the sensitive genitals, creating permanent damage and possible dysfunction. ${ }^{10}$ Both partners may experience sexual dysfunction as a result of painful intercourse and reduced sensitivity following clitoridectomy and narrowing of the vagina. FGM may leave a lasting mark on the life and mind of a woman. The woman may suffer from anxiety, depression, chronic irritability, frigidity, and marital conflicts. ${ }^{3}$

Although FGM is widely recognized as a consequence of patriarchal oppression and the subjugation of women, a number of ethnographic studies report that men are often not involved in the decision to circumcise girls. Circumcision is considered "women's business" and, to a large extent, supported and transmitted by women. For example, the practice of infibulation among African women has been initiated and supported by women. It is usually done among women and the practice often goes unnoticed by males. ${ }^{11}$ Infibulation is believed to promote health and fertility, and also claimed to make sexual intercourse more pleasurable for the

African Journal of Reproductive Health Vol. 10 No.2 August 2006 
male. Several studies have also mentioned marriageability as one of the main reasons for performing the practice. ${ }^{11,12,13,14}$ In many societies where FGM is practiced, it is considered as a way of preparing a girl for marriage, as a prerequisite for marriage, increasing the prospects for marriage, and providing possible security through marriage, among others. Although FGM is considered as a prerequisite for marriage, it is less clear from the available literature by whom it is considered to be a prerequisite. Is it the girl's parents, the potential groom's male or female relatives, or the potential groom himself? Nevertheless, the role of marriageability in perpetuation of the practice is considered in the following realm: FGM fosters virginity because the physical barriers associated with it often reduce the chances of being raped and the attenuation of sexual desire protects some oversexed women from infidelity.

In Ghana, research conducted in the KND affirmed that a circumcised girl has a better chance of marriage than an uncircumcised girl. ${ }^{15}$ Likewise, a study in the eastern part of Ethiopia indicated that FGM is becoming less of an issue for marital reasons but men still appear to prefer marrying circumcised women. ${ }^{16}$ Marriage in the African traditional system is an important element of life and is tied to traditional practices such as FGM. As a result women often cannot ignore but go through pain to achieve fulfilment in their lives. Men and their preferences towards circumcised women may have contributed to the perpetuation of the practice of FGM in Africa. In Sudan, a study on male attitudes towards FGM showed that $35 \%$ of young men and $80 \%$ of grandfathers preferred to marry a circumcised woman. ${ }^{17}$ In Ethiopia, women believed that men fully support the practice and also thought that men preferred to marry circumcised women because the women would then not be sexually overactive and unfaithful. ${ }^{16}$ This has made women believe that if men would openly state a preference to marry non-circumcised women,
FGM would probably cease, since the tradition per se has no value.

However, findings from a study in Sudan revealed that most young men would have preferred to marry a woman without FGM, giving sexual satisfaction as the reason for that response. ${ }^{17}$ Another view on men's position about the practice was drawn from a survey conducted in Sudan in 1994, with husbands who had one infibulated wife and one noninfibulated wife. Eighty nine percent of the husbands stated emphatically that they preferred nonexcised or sunna-circumcised (mild type) women sexually. ${ }^{6}$

It follows that male experiences with circumcised women could contribute to the eradication of the practice. If their beliefs and attitudes towards the practice were widely known, false expectations related to FGM would be halted. To date little research has been done to substantially guide policymakers. Although men are seen as role players in perpetuating the practice of FGM, little is known in Ghana about the factors associated with their preference for circumcised women. Investigating their preference for circumcised women would be extremely useful, as women reported that the practice would only stop if men would accept or prefer to marry non-circumcised women. ${ }^{14}$

This study seeks to determine the factors associated with males' preference for circumcised women in KND in northern Ghana where the social structure is patriarchal and men play an important role in decision-making related to reproduction and family planning behavior. It is also important to point out that the Government of Ghana passed a FGM law in 1994 which calls for prosecution of anyone circumcising a girl. Thus, the law does not influence men's willingness to state a preference for a circumcised women. Based on the literature reviewed earlier, we consider a number of potential factors that may be related to males' preference for circumcised women such as ethnicity, religion, education, marital status, whether respondent lived in or 
outside KND during most part of his life, age, whether one witnessed a circumcision procedure, and parental education (for adolescents aged 12-24).

\section{Study Setting}

The KND covers an area of 1,675 sq $\mathrm{km}$. The district is bordered by Burkina Faso to the north, Bongo and Bolgatanga districts to the east, Builsa and Tumu Districts in the west and Walewale district to the south. For research purposes, the Navrongo Health Research Centre (NHRC) divided the locality into five zones: east, west, north, south, and central. There are two main ethnic groups in the district: the Kassena occupy the north and the west zones whereas the Nankana are located in the east and south zones of the district. The minority Bulsa reside in the southern part of the district. The survey was conducted in the east and west zones. These zones vary in their ethnic, linguistic, and traditional make-up. At the time this study was being conducted, the district's population was roughly 142,000 (53\% females; $47 \%$ males) and largely rural (90\%) with $10 \%$ urban. The irrigation scheme in Navrongo, the district capital, has made it possible for increasing agricultural production through dry season farming of rice and tomatoes. The KND's economy is largely agrarian with traditions steadily changing. Households are grouped into extended family units or compounds each headed by a male patriarch. Lineage customs, religious practices, marriage patterns, and other social characteristics of the population are traditional but are progressively affected by the social, economic, and political trends that have changed society in southern part of Ghana. ${ }^{18}$

\section{Methods}

\section{Study Design}

The FGM baseline survey was conducted in the KND in 1998-1999 by the NHRC. Respondents were all males from the west and east zones of the district. Simple random sampling technique was used to select the compounds (defined as a cluster of rooms-mostly traditional round rooms-that are walled together and housing a family or families with a common ancestry) for the primary study. Compounds with at least one adolescent male were randomly selected from the east and west zones of the KND using the Navrongo Demographic Surveillance System (NDSS). The NDSS is a continuous population registration system that has been assessing the demographic dynamics (births, deaths, and migration) of the KND since 1993.

The sample was divided into adolescents aged 12-24 years and adults aged 25 years and above in order to facilitate comparison of adolescent and adult beliefs about FGM. All adolescent members of the selected compounds were interviewed. Adults were interviewed based upon their relationship as parents to or caretakers of one of the interviewed adolescents. A total of 3,000 respondents were sampled for interviews.

The Ministry of Health Ghana granted ethical clearance for the survey research. Community consent was obtained from chiefs and people of the two zones of the KND before the study was undertaken. Community members were assured of anonymity and confidentiality for survey participants.

\section{Data Collection}

Training of 31 fieldworkers and two field supervisors was conducted from November to December 1998. The questionnaire was translated into Kassem and Nankam, the languages that were used for the interviews. In addition, the questionnaires were pre-tested in the central zone as part of the training process and also to determine questions that needed revision. During the interview, compound heads and interviewees were again briefed on the subject matter and consent obtained orally in the presence of witnesses before the interview procedure.

The survey fielded two separate questionnaires for each sex and consisted of two sections. Section

African Journal of Reproductive Health Vol. 10 No.2 August 2006 
A was administered to all respondents while section $\mathrm{B}$ was only administered to respondents who had ever heard of FGM. Section A gathered information on personal and parents details whereas section $B$ gathered detailed information on knowledge, attitudes, beliefs, the law banning the practice, and the design of an intervention programme to end the practice. The information in sections $\mathrm{A}$ and $\mathrm{B}$ for females were similar to that in the males' questionnaires, except that additional questions relating specifically to women's circumcision status and detailed knowledge of the procedure were included in the female questionnaire.

Data collection started in mid-December 1998 and ended in March 1999. Some problems were encountered during the data collection process. For example, some of the fieldworkers complained that some of the respondents (especially those below 15 years of age) did not understand the questions. These became incomplete interviews. Some respondents who lived around irrigation dams and other water sources were not available to be interviewed because of dry season farming and the need for them to be in the field. In addition, some respondents migrated to the southern part of Ghana in search of jobs. A decision was taken that a form be deemed incomplete if a respondent was not interviewed after three or more visits. Problems encountered were discussed and resolved at weekly project meetings. Field visits were made by senior project staff to observe and resolve any problems associated with the logistics of data collection.

Out of the sampled 3,000 male respondents, a total of 2,883 respondents were interviewedrepresenting $96 \%$ response rate. The total interviews comprised of 1,724 males aged 1224 years and 1,159 males were 25 years and above. The analysis for this paper only included 2,520 respondents $(1,406$ adolescents; 1,114 adults) of the original sample because of few discrepancies such as incomplete information from the questionnaires. Permission to use the data for this study was granted by the NHRC.

\section{Statistical Analysis}

Descriptive statistics (frequencies and percentages) were used to describe the data. Where relevant, the chi-square test was used to test for group differences. All $\mathrm{p}$-values were two-tailed, and a value of $\mathrm{p} \leq 0.05$ was considered significant. To adjust for multiple determinants of male preference, multivariate analysis was performed using logistic regression by employing STATA statistical software, version 8 for Windows. The outcome variable for our analysis was male preference for circumcised woman (yes, no), which was ascertained by the question on whether they personally preferred to marry women who are circumcised.

\section{Results}

Table 1 presents the socio-demographic characteristics of the study population. The sample consists of 2,520 males of whom $55.8 \%$ are aged $12-24$ years and $44.2 \%$ are aged 25 years and above. The mean age for the sample is 30 years. Results further show that there are two dominant religious groups in the east and west zones of the KND: traditional religion (52.6\%) and Christianity (46.2\%). Muslims are a minority at $1.2 \%$. The youngest age groups has more $(63.8 \%)$ Christians than traditionalists (34.8\%). In contrast, the oldest age group has more $(74.9 \%)$ traditionalists than Christians $(24.2 \%)$. This distribution may be related to the fact that the young may be exposed to Christianity more than the old who are the custodians of traditional religion.

Majority of the respondents are either Kassena $(52.6 \%)$ or Nankana (47.4\%). Further, the percentage composition of ethnicity by age group is similar to that for all age groups combined. Fifty-two per cent of the respondents were never married, $19.3 \%$ married once, and 
$29.4 \%$ married more than once. As expected, the youngest age group has more $(92 \%)$ unmarried individuals than the oldest age group (3\%). In addition, $54.1 \%$ of the respondents ever attended school while $45.9 \%$ reported no schooling. School attendance is high in the youngest age group at $76 \%$ and lowest among the oldest age group at $26 \%$. Out of the 1,360 respondents who reported ever been to school, $54.5 \%$ were currently in school and $45.5 \%$ had completed or dropped out of school. Current school attendance is high among the youngest compared with the oldest individuals. Of those currently in school, $65.5 \%$ were in primary school, $24.9 \%$ were in JSS/ Middle schools, and 9.5\% reported attaining secondary or higher levels.

Adolescent males were asked about their parents' educational level in an attempt to examine the relationship between parents' education and male preference for circumcised women. Approximately $72 \%$ of the adolescents reported that their fathers had no education and $83 \%$ reported that their mothers were not educated. The survey gathered information on whether the respondent lived most part of his life in or outside of KND. This information is important because people who lived out of the district for a considerable period are considered as exposed to new ideas and cultures, which are different from those practiced in the KND. Results show that among all males, $11.1 \%$ lived most part of their life outside of KND whereas $89.9 \%$ lived in the district. However, majority $(16 \%)$ of males in the oldest age group lived outside the KND compared with $7 \%$ of males in the youngest age group.

The bivariate analysis of the association between the respondents' preference for circumcised women and sociodemographic factors (Table 2) demonstrate that, education level, ethnicity, religion, marital status, age, and residence were significantly associated with preference for circumcised women.

Table 3 presents the relationship between males' preference for circumcised women and six demographic factors. Education level is significantly related to male preference for circumcised women in future. The baseline model shows that those with primary education were three times more likely to prefer circumcised women than those with secondary/higher education. Illiterate males are about 2.5 times more likely to prefer circumcised women than the highly educated males. The high odds ratios for those who have been to primary schools compared to the illiterate may be related to the fact that the two groups are not significantly different from each other. In Model 2, when we adjust for ethnicity and religion, the odds ratios of education level are attenuated but maintain their robustness as in Model 1. The Nankanas are $75 \%$ more likely to prefer circumcised women than the Kassenas $(p<0.001)$. The traditionalists are $41 \%$ more likely than the Christians to prefer circumcised women.

In Model 3, we add marital status, age, and residence of respondent during most part of his life. We find that these variables are not only significant but also reduce the odds for education level and ethnicity. Nevertheless, the odds of preference for circumcised women by respondents with primary and no education still more than doubles. The Nankanas are $71 \%$ more likely to prefer circumcised women than the Kassenas. And traditionalists are 54\% more likely to prefer circumcised women than the Christians.

\section{Discussion And Conclusions}

In this paper we were interested in examining factors associated with males' preference for circumcised women in an area where the social structure is patriarchal and men play an important role in decision-making relating to reproduction and family planning behaviour. We looked at a number of variables such as age, marital status, religious affiliation, education, ethnicity, and residence. The chi-square test of association was performed to show the relationship between preference for circumcised women and the independent variables.

African Journal of Reproductive Health Vol. 10 No.2 August 2006 
Table 1: Socio-demographic Characteristics of Males by Age Group

\begin{tabular}{|c|c|c|c|c|c|c|}
\hline \multirow[t]{2}{*}{ Characteristic } & \multicolumn{2}{|c|}{$12-24$} & \multicolumn{2}{|c|}{$25+$} & \multicolumn{2}{|c|}{ Total } \\
\hline & $\mathbf{N}$ & $\%$ & $\mathbf{N}$ & $\%$ & $\mathbf{N}$ & $\%$ \\
\hline \multicolumn{7}{|l|}{ Men prefer circumcised women $(n=2515)^{a}$} \\
\hline Yes & 292 & 20.8 & 180 & 16.2 & 472 & 18.8 \\
\hline No & 853 & 60.9 & 856 & 76.8 & 1709 & 68.0 \\
\hline Don't know & 256 & 18.3 & 78 & 7.0 & 334 & 13.3 \\
\hline \multicolumn{7}{|l|}{ Religion $(n=2,508)^{a}$} \\
\hline Traditional & 486 & 34.8 & 833 & 74.9 & 1319 & 52.6 \\
\hline Christianity & 890 & 63.8 & 269 & 24.2 & 1159 & 46.2 \\
\hline Islam & 20 & 1.4 & 10 & 0.9 & 30 & 1.2 \\
\hline \multicolumn{7}{|l|}{ Ethnicity $(n=2,488)^{b}$} \\
\hline Kassena & 698 & 50.2 & 610 & 55.6 & 1308 & 52.6 \\
\hline Nankana & 693 & 49.8 & 487 & 44.4 & 1180 & 47.4 \\
\hline Marital status $(n=2,520)^{a}$ & & & & & & \\
\hline Never married/lived with a woman & 1287 & 91.5 & 30 & 2.7 & 1317 & 52.3 \\
\hline Married once & 101 & 7.2 & 386 & 34.7 & 487 & 19.3 \\
\hline Married more than once & 18 & 1.3 & 698 & 62.7 & 716 & 28.4 \\
\hline \multicolumn{7}{|l|}{ Current marital status $(n=1,201)$} \\
\hline Married/living together & 109 & 92.4 & 984 & 90.9 & 1093 & 91.0 \\
\hline Unmarried $^{*}$ & 9 & 7.6 & 99 & 9.1 & 108 & 9.0 \\
\hline \multicolumn{7}{|l|}{ Ever been school $(n=2,520)^{a}$} \\
\hline Yes & 1069 & 76.0 & 293 & 26.3 & 1362 & 54.1 \\
\hline No & 337 & 24.0 & 821 & 73.7 & 1158 & 45.9 \\
\hline \multicolumn{7}{|l|}{ Currently in school $(n=1,360)^{a}$} \\
\hline Yes & 736 & 68.9 & 5 & 1.7 & 741 & 54.5 \\
\hline No & 332 & 31.1 & 287 & 98.3 & 619 & 45.5 \\
\hline \multicolumn{7}{|l|}{ Education level $(n=1,359)^{a}$} \\
\hline Primary & 733 & 68.6 & 157 & 54.0 & 890 & 65.5 \\
\hline Middle/ JSS & 257 & 24.1 & 82 & 28.2 & 339 & 24.9 \\
\hline Secondary school+ & 78 & 7.3 & 52 & 17.9 & 130 & 9.5 \\
\hline \multicolumn{7}{|l|}{ Father educated $(n=1,386)$} \\
\hline Yes & 299 & 21.6 & na & na & 299 & 21.6 \\
\hline No & 1000 & 72.1 & na & na & 1000 & 72.1 \\
\hline Don’t know & 87 & 6.3 & na & na & 87 & 6.3 \\
\hline \multicolumn{7}{|l|}{ Fathers' education level $(n=294)$} \\
\hline Primary & 81 & 27.6 & na & na & 81 & 27.6 \\
\hline Middle/ JSS & 64 & 21.8 & na & na & 64 & 21.8 \\
\hline Secondary & 70 & 23.8 & na & na & 70 & 23.8 \\
\hline Don't know & 79 & 26.9 & na & na & 79 & 26.9 \\
\hline \multicolumn{7}{|l|}{ Mother educated $(n=1,365)$} \\
\hline Yes & 170 & 12.5 & na & na & 170 & 12.5 \\
\hline No & 1126 & 82.5 & na & na & 1126 & 82.5 \\
\hline Don't Know & 69 & 5.1 & na & na & 69 & 5.1 \\
\hline \multicolumn{7}{|l|}{ Mothers' education level ( $n=164)$} \\
\hline Primary & 82 & 50.0 & na & na & 82 & 50.0 \\
\hline Middle/ JSS & 41 & 25.0 & na & na & 41 & 25.0 \\
\hline Secondary & 13 & 7.9 & na & na & 13 & 7.9 \\
\hline Don’t know & 28 & 17.1 & na & na & 28 & 17.1 \\
\hline \multicolumn{7}{|l|}{$\begin{array}{l}\text { Ever lived most part of life } \\
(\mathrm{n}=2520)\end{array}$} \\
\hline Outside Kassena-Nankana (r) & 99 & 7.0 & 180 & 16.2 & 279 & 11.1 \\
\hline Kassena-Nankana District & 1307 & 93.0 & 934 & 83.8 & 2241 & 88.9 \\
\hline Total & 1406 & 100.0 & 1114 & 100.0 & 2520 & 100.0 \\
\hline
\end{tabular}

Notes: "na" - question asked to adolescents only; Some percentages may not add up to 100 due to rounding; " Chi-square test for cell differences significant at $p<0.001 ;{ }^{b}$ Chi-square test for cell differences significant at $p<0.01$; ${ }^{*}$ Includes the widowed $(3.3 \%)$, divorced $(3.9 \%)$, and separated $(1.2 \%)$.

African Journal of Reproductive Health Vol. 10 No.2 August 2006 
Table 2: $\quad$ Association Between Males' Preference for Circumcised Women and Selected Independent Variables

\begin{tabular}{lccc}
\hline & $\begin{array}{c}\text { Chi-square } \\
\text { Value }\end{array}$ & P-value & $\begin{array}{c}\text { Order of } \\
\text { strength }\end{array}$ \\
\hline Variables & & & \\
Education level & 34.10 & 0.000 & 1 \\
Ethnicity & 27.94 & 0.000 & 2 \\
Religion & 25.48 & 0.000 & 3 \\
Marital status & 21.25 & 0.000 & 4 \\
Age & 18.76 & 0.000 & 5 \\
Residence & 4.74 & 0.029 & 6 \\
Ever been to school & 0.51 & 0.476 & 7 \\
\hline
\end{tabular}

Table 3: $\quad$ Logistic Regression of Males' Preference for Circumcised Women

Odds ratios ( $95 \%$ C.I.)

\begin{tabular}{|c|c|c|c|}
\hline Characteristics & Model 1 & Model 2 & Model 3 \\
\hline \multicolumn{4}{|l|}{$\overline{\text { Education level }}$} \\
\hline \multirow[t]{2}{*}{ Secondary/Higher (r) } & 1.00 & 1.00 & 1.00 \\
\hline & $1.56(0.75-3.24)$ & $1.71(0.76-3.80)$ & $1.60(0.72-3.59)$ \\
\hline Middle/JSS & $3.05(1.56-5.98)^{* *}$ & $2.89(1.36-6.13)^{* *}$ & $2.60(1.22-5.53)^{*}$ \\
\hline Primary & $2.48(1.27-4.82)^{*}$ & $2.19(1.02-4.68)^{*}$ & $2.39(1.11-5.15)^{*}$ \\
\hline \multicolumn{4}{|l|}{ None } \\
\hline \multicolumn{4}{|l|}{ Ethnicity } \\
\hline Kassena (r) & & 1.00 & 1.00 \\
\hline Nankana & & $1.75(1.39-2.21)^{* * *}$ & $1.71(1.35-2.16)^{* * *}$ \\
\hline \multicolumn{4}{|l|}{ Religion } \\
\hline Christian (r) & & 1.00 & 1.00 \\
\hline Traditional & & $1.41(1.09-1.84)^{*}$ & $1.54(1.18-2.03)^{* *}$ \\
\hline \multicolumn{4}{|l|}{ Marital status } \\
\hline Never married/lived with a woman (r) & & & 1.00 \\
\hline Married once & & & $0.72(0.44-1.19)$ \\
\hline Married more than once & & & $0.86(0.49-1.49)$ \\
\hline \multicolumn{4}{|l|}{ Age group } \\
\hline $12-24(\mathrm{r})$ & & & 1.00 \\
\hline $25+$ & & & $0.84(0.50-1.41)$ \\
\hline \multicolumn{4}{|l|}{ Ever lived most part of life } \\
\hline Outside Kassena-Nankana (r) & & & 1.00 \\
\hline Kassena-Nankana District & & & $1.38(0.90-2.10)$ \\
\hline $\mathrm{N}$ & 2,128 & 2,080 & 2,080 \\
\hline LR chi2 (df) & 22.26 & 55.32 & 64.25 \\
\hline Prob > chi2 & 0.0000 & 0.0000 & 0.0000 \\
\hline
\end{tabular}

Notes: * $p<0.05 ; * * p<0.01 ; * * * p<0.001 ;$ " $r$ " - reference category. 
This study revealed that low levels of education of the respondents and their preference for circumcised women are highly related. A community-based study on the change of practice of FGM in a Sudanese village also demonstrated that the level of education of the woman plays an important role in her decision or attitude towards the practice. However, this research is contrary to the same study that revealed that there was no such difference related to level of education among young men. ${ }^{16}$ The ethnic origin of the respondent also plays an important role when it comes to the decision as to whether to marry a circumcised or uncircumcised woman. The Nankanas were more likely to prefer a circumcised woman than the Kassenas. This is expected considering that most marriages occur within ethnic groups although a few interethnic marriages are also common since the Kassena and Nankana have a common historical and cultural background. It is also common these days for people to marry outside the KND. In the past, marriages were often arranged by families with the consent of the groom. Presently, the choice is made by men but with the consent of the parents. It is in few instances that marriages are arranged by parents. Thus, to a large extent, men are the prime decision makers in the selection of their wives.

In addition, the study found that Christians are less likely to prefer circumcised women than non-Christians. The reason could be that the east zone of the KND is dominated by the Nankanas who are largely traditionalists and have low levels of education. In contrast, the west zone is made up mostly of the Kassenas who have higher education than the Nankanas and largely practice Christianity. These ethnic differences are, inter alia, partly related to the way Christianity (along with education) was first introduced among the people of the KND. Christianity was first introduced among the Kassenas because the early missionaries had few problems with their language (Kassem). This resulted in the Kassenas embracing social changes in their lives that were driven by Christian doctrines more than was the case with the Nankanas. ${ }^{19}$

The data on which this study is based have some limitations. First, the primary data might have been affected by sampling errors normally associated with various stages of the research process from study design to data processing. Appropriate measures such as careful selection of respondents using simple random sampling, several revisits to interview respondents who were not found in their compound for the first or second attempts, and data validation were however taken to minimise the effect of such errors on the data during the primary data collection phase.

Second, the survey data were collected in 1998 and males' preference for circumcised women at the time of the survey might be different from their current preferences because of an intervention programme in place. However, the traditional practice is ingrained in the communities such that, changes in attitudes of community members with regard to the practice are a gradual process and that these findings may still be relevant for policy decision-making.

Third, it is not clear from our study whether female circumcision is important in influencing marriageability in this population. And lastly, it is not clear when or how men participate in the decision about the perpetuation or discontinuation of FGM. All these issues could be addressed or clarified in subsequent qualitative research.

Nevertheless, the findings outlined here have some implications for policy. First, FGM studies should be included in the school curricula and ensuring that the study of FGM and its consequences are made compulsory in all schools. People should be told about the physiological facts about FGM. It will help if girls and boys should be educated about the advantages of natural genitals and disadvantages of FGM in order to eliminate any misconceived ideas about the benefits of FGM. ${ }^{11}$ This will ensure that the 
youth are oriented towards the harmful and social consequences of FGM at an early stage. Second, the intervention programme activities that are going on in the KND should target both in-and out-of-school males. They should be targeted with specific activities tailored for their participation. Third, religious leaders should be involved in the eradication process. Priests, pastors, and imams should be encouraged to preach against the practice in the churches and mosques. In addition, the traditional practitioners and soothsayers should be targeted as a special group in the eradication process. Some FGM practitioners practice FGM for a living. Therefore, ensuring that the public is made aware of the dangers associated with FGM will reduce the demand for circumcision and ultimately bringing the whole practice of FGM to a halt. Lastly, community change agents in the intervention communities of the district should intensify their efforts in the eradication campaigns by, among other things, encouraging men who disapprove of FGM to openly voice their disapproval and make their position widely known. One way to do this would be to form associations of parents who pledge not to mutilate their girls nor let their sons prefer to marry the mutilated women. This may possibly lead to change over a considerable time.

\section{REFERENCES}

1. World Health Organization. Female genital mutilation: report of a WHO Technical Working Group. Geneva, 1995; 17-19 July. Geneva, World Health Organization, WHO/FRH/WHD/96.

2. Toubia N. Female Genital Mutilation: A Call for Global Action. 2nd edition. New York: RAINBO, 1995.

3. Dorkenoo E. Combating female genital mutilation: an agenda for the next decade. World Health Statistics Quarterly 1996; (1992) 49(2): 142-147.

4. Carr D. Female Genital Cutting: Findings from the Demographic and Health Surveys Program. Calverton: Maryland, USA, Macro International Inc., 1997.

5. ORC Macro. Female genital cutting and the Demographic and Health Surveys. http://
www.measuredhs.com/gender/fgc-cd/FGCDHS.cfm, 2005; last accessed 22 August 2005.

6. Dorkenoo E. Cutting the Rose, Female Genital Mutilation: The Practice and its Prevention. London: Minority Rights Publications, 1994.

7. Amnesty International. Working Together for Change: Stop Female Genital Mutilation. Accra, Ghana, 1996.

8. Navrongo Health Research Centre. Findings from a Baseline Survey on the Prevalence of Female Genital Mutilation in the Kassena-Nankana District, Ghana. Community Health and Family Planning Project. Navrongo, Ghana: Navrongo Health Research Centre, 1998.

9. Jones H, Diop N, Askew I and Kaboré I. Female genital cutting practices in Burkina Faso and Mali and their negative health outcomes. Studies in Family Planning 1999; 30(3): 219-230.

10. Shell-Duncan B. The medicalization of female 'circumcision': harm reduction or promotion of a dangerous practice? Soc Sci Med 2001; 52: 1013 ?1028.

11. Mackie G. Ending footbinding and infibulation: a convention account. American Sociological Review 1996; 61: 999-1017.

12. World Health Organization. A traditional practice that threatens health-female circumcision. Chronicle 1986; 40: 31-36.

13. Gruenbaum E. The Islamic movement, development and health education: recent changes in the health of rural women in central Sudan. Soc Sci Med 1991; 33(6): 637-645.

14. Baker CA, Gilson GJ, Vill MD and Curet LB. Female circumcision: obstetric issues. American Journal of Obstetrics and Gynaecology 1993; 167: 16161618.

15. Adongo $\mathrm{P}$, Akweongo $\mathrm{P}$, Binka $\mathrm{F}$ and Mbacke $\mathrm{C}$. Female genital mutilation: socio-cultural factors that influence the practice in Kassena-Nankana District, Ghana. African Journal of Reproductive Health 1998; 2(2): 25-36.

16. Missailidis K and Gebre-Medihin M. Female genital mutilation in Eastern Ethiopia. Lancet 2000; 356(9224): 137-189.

17. Almroth L, Almroth-Berggren V, Hassanein OM, et. al. Male complications of female genital

African Journal of Reproductive Health Vol. 10 No.2 August 2006 
mutilation, Sudan. Soc Sci Med 2001; 53: 14551460.

18. Debpuur C, Chirawurah D, Wontuo P, et. al. The Navrongo Demographic Surveillance System: 2002 Report to the Rockefeller Foundation. Community Health and Family Planning Project Documentation Note number 47. Navrongo, Ghana: Navrongo Health Research Centre, 2002.
19. Doctor HV, Sakeah E and Phillips JF. Trends in religious affiliation among the Kassena-Nankana of northern Ghana: are switching patterns identical by gender? Paper presented at the Annual Meeting of the Population Association of America, Philadelphia: Pennsylvania, March 31 to April 2, 2005. 